\title{
Leadership Progression of Muslim Male Teachers: Interplay of ethnicity, faith and visibility
}

$\underline{\text { Saeeda Shah with Jalil Shaikh }}$

Organisational structures, institutional practices, societal assumptions and subscribed concepts impact significantly on individuals' career aspirations and progression.

Progression to educational leadership positions is no exception. In fact it emerges as a highly complex process with sensitive political underpinnings in the emerging multiply diverse societies. Research confirms the effect of factors such as race, colour, ethnicity, gender and others in shaping career paths towards leadership positions; however, the level of significance for each factor is embedded in context and case.

Earlier feminist literature highlighted the traditional association of leadership with White male as a feudal patriarchal construction of male power over females, which reproduced gender discrimination in the public domain, particularly at senior leadership level. More recent research unveils another strong equation which is between race/ethnicity and career progression, drawing attention to the underrepresentation of people from BME backgrounds in educational leadership roles (Bush, Glover and Sood, 2006; Mackay and Etienne, 2006a, Lumby and Coleman, 2007; Turner, 2006). The interplay of race/ethnicity with career progression is also highlighted by the National Statistics as a barrier to career destinations reflected in nominal presence of BME in senior positions. However, there is a visible gap in research on the issue of how visible religious affiliations (Home Office, 2001) affect career progressions of people from BME backgrounds.

Much research (London Leadership Centre, 2002; McKenley, Mayhead and Gordon, 2002; Bush, Glover and Sood, 2006; Coleman, 2002; Mackay and Etienne, 2006a; Osler, 2003) has been carried out into why BME teachers are not becoming leaders in the respective educational institutions, and into the factors that hinder their career progression and development; however, no research has been carried out specifically on Muslim teachers. There are 1.6 million Muslims in Britain, comprising ' 3 per cent of the total population and over half (52 per cent) of the non-Christian religious population' (National Statistices, 2001). They are the largest faith group in the country after the Christians, and unlike some other faith groups Muslims tend to highlight their religious identity (Brah 1996; Jacobson 1998; Modood 1990; Modood et al 1997; Nielsen 1987). Furthermore, the age profile by faith draws attention to another significant detail that $66 \%$ of the Muslims are under 35 years while for example, only $39 \%$ of Christians fall within this category. Thus, the Muslims have the highest youth profile in UK (National Statistices, 2001), which further emphasises the need for appropriate policies and practices to fully avail the potential of this large workforce on the one hand, and on the other hand it justifies the need to investigate the barriers to their career progression, using faith as a category for analysis.

The statistics highlight that in spite of a high youth population, the Muslims are lowest in education and employment (Abbas, 2004). This is a cause for concern, not only for social justice and inclusion but also for engaged citizenship and societal cohesion. There is little research available on the experiences of Muslim teachers in the British State Schools system and their professional journeys. The interface between the West and the Muslims is underpinned by the histories of conflict and 
contending claims. Multiple social, economic, strategic, historical and political factors have added to the complexities of this interface in the British context, made more sensitive in the post 9/11 and 7/7 scenario. Experiences of discrimination and marginalisation by the Muslims can further add to the complications, shaping perspectives and identities as 'we are positioned by, and position ourselves within the narratives of the past' (Hall, 1993, p. 394). Therefore, in the light of challenging times for Muslims around the world and more specifically how they are perceived in the West, this paper contributes to a very important debate.

The paper explores the career paths of Muslim male teachers (MMTs) in English secondary schools to investigate potential barriers to their career progression to senior leadership positions. The underpinning argument is that an awareness of the barriers can be the way forward towards developing policies, procedures and strategies to remove or at least control the barriers. On another level, the paper also contributes to the complex and sensitive debates on diversity, equal opportunities, social justice and inclusion by exploring the perceived marginalisation of this particular group of workforce and its impact on their career destinations. The paper also contributes to the existing debates by drawing attention to a new sub-field in the BME literature, to develop insights into the additional complexities that religious affiliation brings and thus as a consequence open up avenues for these complexities to be addressed. Finally, in a context of media hype of associating terrorism with young male Muslims, it becomes highly pertinent to explore male Muslim role models as they are visible for young Muslims in education.

\section{Methodology}

The paper draws upon a small study carried out to explore the career development and progression of a sample of Muslim male teachers (MMT) working in the state sector in London schools in order to establish their perceptions of what aids or hinders their progress to leadership positions within state school system. The study investigated the career aspirations of MMT and what happened to them whilst attempting to envisage these aspirations. The intention was to debate the barriers, how the barriers were overcome by the successful MMT, and to identify the facilitators or the strategies that proved effective in this regard to inform future policy deliberations. The research was set within the wider conceptual context of equality, social justice and inclusion and how these relate to the issues of diversity in the workforce in mainstream state schools.

Due to the practical constraints and pragmatics involved, the focus of the study was limited to one region. London was selected as a relevant case for the study particularly because of its demographics. According to a DfES Survey (2002) cited in a report by the Mayor of London (2004), BME pupils made up 43.5\% of the number of pupils in London schools in 32 boroughs. This percentage is far higher in Inner London schools where the population density of BME people is far greater (Campbell-Stephens, 2006). However, the number of BME teachers in London schools is highly unrepresentative of the student population, making up only $7.4 \%$ of the total number of teachers (London Development Agency, 2004). Furthermore, the percentage of BME staff in leadership positions at any level is even smaller than the percentage of teachers (Bush, Glover and Sood, 2006; Mackay and Etienne, 2006a). This not only signals a lack of equal opportunities for BME, but also invites attention to other serious issues such as that BME students, as a consequence, are lacking the 
role models that they can relate and aspire to (Osler, 1997). More importantly, this signals unavailability of the expertise of BME teachers and leaders who can better understand, empathize with and cater more closely to their needs (Campbell-Stephens, 2006; Gilborn, 2001, 2005; Shah, 2006).

The data for this study was generated using a semi-structured questionnaire and then 'follow up' interviews. The questionnaire addressed the main areas of:

- the career aspirations of these teachers, the career paths they chose and how they planned their career progression;

- the facilitators and obstacles to their career progression, including any types of discrimination, encouragement or help they may have received.

The study was originally intended to be conducted throughout all the 32 London boroughs to attempt as fuller a picture as possible of MMT working in London state schools and all members of the Muslim Teachers Association (MTA) were contacted. However, as with other similar research (Bush, Glover and Sood, 2006) finding willing participants in all the boroughs proved to be difficult and given the gap in information required for the sample population on national databases (Ofsted, NCSL and DfES), 'snowball' sampling strategy was attempted (Cohen and Manion, 1994, p. 88). The initial contacts/participants were used as informants to identify further participants who could fulfil the requirements of being Muslim males with at least five years teaching experience and /or currently in middle management or senior management positions. However, most participants did not know any such colleagues (or did not acknowledge they knew any), highlighting the probable lack of networking amongst the intended research sample, and also signalling complex discourses at play that constructed these responses. It was during interviewing that it emerged that the potential sensitivity of the study caused some teachers to refrain from participating due to fear of unwanted ramifications at work. For example, one of the research participants telephoned the researcher to apologize for not being available for the follow up interview. This was despite the fact that he had previously spoken to the researcher about being discriminated against at his school, stating that if he was not a Muslim or an Asian Muslim, he would not have to go through some of the obstacles he was facing at school from the senior management.

Given the context of inhibitions and/or barriers to participation, only ten questionnaires were returned, and six of the respondents expressed willingness to be interviewed, providing their contact details. These participants came from five different boroughs in the East End of London (Tower Hamlets, Newham, Hackney, and Redbridge and Haringey) - with significant numbers of Muslim students in their schools. Six semi-structured interviews (Robson, 2002, p. 270) were conducted. Four interviews were one-to-one, while two teachers who worked in the same school were interviewed together. Each interview lasted between 40 minutes and 1 hour 15 minutes. The appearance of these Muslim male interviewees were also noted down, e.g. whether they had a beard or not etc., in order to evaluate whether certain themes were repeated by similar looking people. Some previous research (Modood, 1997; Bush, Glover and Sood, 2006; Lumby and Coleman, 2007) has discussed the potential effects of visibility on the careers of BME teachers, and the intention was to see whether similar experiences were reported by the research participants in this case. 
The interviews explored the professional experiences of the interviewees, their aspirations when becoming teachers and how these aspirations had materialized throughout their careers. The interviews also provided an opportunity to investigate further which facilitators and barriers impacted on the interviewees' professional development and career progression, and how some participants overcame any such obstacles to become senior leaders.

\section{BME Teacher and Career Trajectories}

Difficulties in recruiting and retaining teachers have been increasing (Ofsted, 2002, p. 4) and the numbers of teachers entering the profession, especially from the BME communities remain low (Basit et al, 2006; 2007; Bush, Glover and Sood, 2006). Despite a recognition of the potential contributions of BME educational leaders and teachers in a multi-ethnic society like Britain (Siraj-Blatchford, 1993; Tomlinson, 1990; Gordon, 2000), their representation is low as educational leaders (Lumby and Coleman, 2007). Various policy measures have been adopted by the government to address the issue although their effectiveness may be questioned. For example, there has been great scepticism with regard to the extent to which the Race Relations Act (2000 and 2003) has impacted on the ground level, especially in state schools (Turner 2006). The DfES (2003) also recognised the lack of implementation of the Race Relations Act (2002), recommending that it should be ensured that 'all staff and governors are aware of legislative changes, particularly regarding equality of opportunities' (Powney et al., 2003, p. 16). Although the Act, like most policy measures, was a positive start in tackling some of the important and deeply grounded issues regarding race and ethnicity, it seemed to lack essential details on matters connected to religious, and more specifically anti-Muslim discrimination or xenophobia which has become widespread in the U.K (Conway, 1997; Sajid, 2005).

Government agencies are sponsoring leadership courses such as 'Investing in Diversity' offered by the London Challenge, which aim to promote the idea of leadership to BME teachers and better equip them to access opportunities to senior leadership positions. These courses aim to tackle some of the challenges that BME teachers have reported, but again do not cater specifically for the needs of Muslim teachers and middle managers. NCSL also pledges to bring on 'more school leaders from a wider range of Backgrounds', and plans to 'support the development of more women and black and minority ethnic leaders' (Corporate Plan, 2008/09), but these are also not specifically focused on Muslims who are the largest faith group after Christianity in the UK. This is a serious neglect on the part of policy makers, particularly in the post 9/11 scenario, as it ignores to take into account the impact of political, social, and global developments on lives and careers of a Muslim teachers, particularly males. Individuals' wider life experiences impact on their professional choices and career trajectories. There is a developing recognition in research of the impact of teachers' own biographies on their education, training and development (Osler, 1997, p. 1).

In the case of Muslims, the professional journey is riddled with complex challenges at all these phases. Increasingly, literature is unveiling social and educational experiences of Muslim learners from childhood to adulthood (Abbas, ??; Ahmed, Basit, 1997; Haque, 2001) detailing negative experiences of the formation phase (Gronn, 1999), which could discourage aspirations. Those who do decide to join the 
teaching profession, experience further barriers at training level (Basit et al, 2006; 2007) and in teaching positions (Osler, 2003; Bush et al, 2006). In spite of the fact that the studies are broadly focused on BME teachers and their experiences, and not on Muslim teachers as such, barriers and challenges specific and unique to Muslims emerge from BME data when participants happen to be Muslim, reflecting a complex mix of Islamophobia and racism.

The perception among the Muslims, particularly among the youth, of being 'targeted' (Ahmed, 2003; Esposito, 2002; Hagopian, 2004) and the processes such as special legislations, police raids, profiling, stop and search practices targeting Muslims and the role of media have all contributed to marginalisation of Muslim in many fields including education and more so in leadership positions. The occurrence of Islamophobic incidents, discrimination and violence, that increased sharply (Conway, 1997) after the 1989 burning of the Satanic Verses, have become manifold since 9/11 and 7/7 (Muir and Smith, 2004; Sheridan, 2004; Van Driel, 2004; Sajid, 2005). Unfortunately, Islamophobic ideas, although deeply ingrained in racist sentiment and religious intolerance have become acceptable to many (Muir and Smith, 2004) as Islam is now conceived to be the new threat to civil society and democracy. As a subsequent, institutionalized Islamophobia has become widely practiced (Muir and Smith, 2004), even in schools where Muslims make up the majority of the school population. Many independent reports have highlighted intentional or at least unintentional institutional discrimination against Muslims (Li and Associates, 2006), drawing attention to 'discrimination through unwitting prejudice, ignorance, thoughtlessness and stereotyping, which disadvantage individuals/groups' (p. 10). This paper confirms from the data that the MMT suffer different kinds of discrimination and obstacles in their career progression, particularly towards leadership positions. However, much of the discrimination reported is covert in nature. The major factors underpinning this discrimination are identified through the data as being: Islamophobia; perceptions of visibility, and a lack of understanding of the issues relating to diversity.

\section{Islamophobia}

Islamophobia refers to 'an irrational distrust, fear or rejection of the Muslim religion and those who are (perceived as) Muslims' (Barry van Driel, p. 3). It is endorsed by an 'unfounded hostility towards Islam, and therefore, fear or dislike of all or most Muslims' (Conway, 1997, p. 1). It is manifest in vilification and demonization of Muslims, endorsing negative attitudes, violence, harassment, discrimination, and stereotyping. It suggests a form of cultural racism (Modood, 1997) not necessarily originating from contempt towards other colours but out of a dislike or hatred for Muslim culture. Islam is increasingly being portrayed as a threat to social cohesion and integration in the British Society and the 'Western Way of Life' (Allen, 2004). The discourses of social cohesion and 'the British way of life' further emphasise an inherent difference and incompatibility between Islam and British Multiculturalism (Abbas, 2004; Allen, 2004), alienating and marginalising the Muslims.

The effect that Islamophobia exercises on the underachievement of Muslim pupils in UK schools has been widely recognized (Richardson, 2004b; Richardson, 2004a; AMS, 2004), Islamophobic incidents show the depth to which Islamophobic discrimination or ignorance are prevalent amongst teaching staff, educational leaders 
and school governors (Sheridan, 2004). However, it seems that no real attention has been given especially in Leadership and Teacher Training programmes to educate the participants (Haque, 2004).

Muslim male teachers participating in this study generally felt very alienated in the current climate of mistrust of Muslims due to the threat of so called Islamic terrorism and its portrayal in the media. Some of the teachers were afraid to make networks with other Muslim teachers due to a fear they would be labelled 'extremists'. An atmosphere of feeling constantly watched and scrutinized came up regularly in their responses. They even seemed reluctant to participate in the study: not knowing who the researcher was, or his intentions, many respondents might have felt it would be better not to participate, and thus avoid any adverse reaction to it from any of the security services, as obvious from this quote:

I do feel that Muslims here are feeling alienated, with regards their status in the community. Therefore they are very reluctant to go to or get involved in various activities (where networking takes place) because of the media. In that sense I did feel when you approached me (to participate in the research) 'what is this all about? What is it going to be used for? But Alhamdulillaah (all praises are for God) after talking to you I felt reassured.

Some teachers did not want to bring any unnecessary attention to themselves, and felt afraid to talk to other visible Muslims in public because of the fear of being found guilty by association, in the event that the person was being monitored by security services and they could become targets by proxy:

It's a difficult one. I'm a Muslim but because of the media and the way things are being portrayed it is very difficult. For example sometimes when I'm talking to an Arab brother or someone, I think 'Oh my God' are they being watched. (Research Participant)

The participating teachers felt that discriminatory attitude towards Muslims in the wider community was a major contributing factor for the lack of Muslims in senior management positions. Several teachers commented that they felt that many people involved in the recruitment processes did not see Muslims as leaders in mainstream schools and as such discouraged them from applying for promotion. One participant who had been a head of year and was currently a head of department, was told that he was too ambitious and was wanting things too soon when he told his head teacher he wished to apply for the FL programme to become an associate assistant head teacher. Sharif ${ }^{i}$ commented that he was one of many Asian Muslim males at his school to be discouraged from applying for promotion and told they were not yet ready. He further argued that white members of staff, who he believed had either the same or less experience than him were being encouraged to be ambitious and take further responsibility in the school:

there are people being encouraged and some that are not, that happen to be Muslim. I think there are some people - not all of them, that don't see Muslims in senior positions. They are told they are not ready for these positions. The feeling is that there is some kind of discrimination going on. 
Because in terms of competency and ability we don't see what they are talking about!

Muhammad who had secured an assistant headship recently in another borough with less Muslim students, had applied on several occasions for an internal promotion but was unsuccessful. He was convinced that his school and borough were intentionally not employing Muslim males in senior management positions:

People are very subtle. However, when you see it affecting a lot of Muslims it makes you wonder. How can it happen to all of us who are capable? Are we all of less ability? For example, it also happened to a colleague who applied for promotion but was not given it - although he had served the school well and got tremendous results in his department. Why was he declined? I don't know! You can see other white members of staff who got the promotion (who) don't have the same track record or the same presence and haven't achieved as much in the school.

A shared perception was that being a Muslim candidate it was more difficult to get a job unless you were a great deal better then other candidates. Karim, describing his experiences at interviews, felt that he had always had to be not only better than other candidates in order to get the job, but disproportionably better. Other teachers echoed the same sentiment:

They need to see no one is better. If you are equal you have no chance. (Bilal)

Islamophobic ideas and attitudes of some head teachers appear to have played a negative role in the career progression of Muslim teachers, which confirms generic findings of other research (Conway, 1997; Allen, 2004; Sheridan, 2004; Sajid, 2005). These ideas and attitudes are largely attributed to media presentation of specific happenings as generalisations, creating misconceptions, misunderstanding and misreadings with negative impact on affected groups and communities. These seem to have stronger impact on career progression of Muslim male teachers. The huge literature on Islamophobia itself is a strong indicator of the discrimination Muslim teachers must be subjected to. Many studies have highlighted marginalisation of BME teachers (Bush, Glover and Sood, 2006; Lumby and Coleman, 2007; Shah, 2006), and women teachers (Coleman, 2002), including even Muslim women teachers (Osler, 2003), but there is no study with explicit focus on marginalisation of Muslim male teachers in the present day context of Islamophobia and an un-informed loudly propagated association between Islam and terrorist activities (Esposito, 2002). Gender in interplay with faith in this case has become a factor for marginalisation.

\section{Norm of Visibility: what a leader should look like}

There was a strong perception amongst MMT that they are not seen as potential school leaders in mainstream schools due to being different from what is considered to be the norm by those in positions of power. Just as women may be seen as 'in the wrong place' (Gold, 2006), some school leaders may feel that Muslim teachers are not 'naturally' (Lumby, 2006) able to fulfil senior roles in schools. This however, is not a new finding, DiTomaso and Hooiberj (1996) discuss that leaders 'often exclude candidates from BME and other diverse backgrounds due to a 'perceived 
incompetence' (p. 180). This study endorses 'leader prototypes' (Foti and Miner, 2003), where people unconsciously have an inbuilt stereotype of what a leader should look like and thus although believing they are acting in relation to equity when appointing new leaders, tend to discriminate on the grounds of those inbuilt beliefs. Discrimination is more likely, the more visibly different the teacher is to what is considered to be the norm (Milliken and Martins, 1996; Modood, 1997). Thus those who did things differently would be seen as 'outsiders' or part of an out-group. Lumby and Coleman (2007) also show how this type of discrimination can be manifested both consciously and intentionally, whilst not being considered discriminatory. They describe how an impetus to appoint a leader in one's own likeness was made explicit in another case organization by a senior leader of that organization:

When you appoint, there is a tendency to appoint one of your own, to identify with someone, with their background or their demeanour...If you stood back and said what is it we need?...I need someone who is different to me, that would bring a completely different viewpoint to the college, it's much more challenging. It is more challenging to the team and more challenging to you individually to deal with someone who doesn't see things the way you do. (Senior Leader, individual interview in Lumby and Coleman, 2007, p. 40)

In spite of increasing numbers of BME students in higher education (National Statistics), "there is clear evidence that the higher echelon and higher status jobs are held disproportionately by white males' (Lumby and Coleman, 2007, p. 60).

The interview responses indicate a perceived bias among senior leaders towards employing people similar to themselves:

If you know the right people and your face fits then you got the job no matter who else applies. They just employed a white lady... She only had about two years of teaching experience at her old school...she was seeing one of the senior management team. Another black teacher, not a Muslim, has done the same job as acting head of department three times but never got the job. He left and became a head of department in another school - he is now a deputy head!

In an investigation into BME leaders' access to career progression through the NPQH (London Leadership Centre, 2002) $70 \%$ of the BME school leaders participating in it reported that issues of ethnicity and racism have had a negative impact on their career; the majority of these were men. These feelings were endorsed by the research participants who strongly believed that:

The SMT should represent the community we have here. From what we have seen, people may not be employed due to other (hidden) agendas. For this reason senior management would prefer to work with people similar to themselves, thus there is a reluctance to work with people more overtly religious. The head teacher has often commented this school is a secular school - not a Muslim school! 
Nine out of the ten responding teachers complained that they had been discriminated against at some time in their careers and especially when applying for jobs and promotion, and associated it with being visibly Muslims. However, the types of discrimination experienced were often very subtle and difficult to prove. The tenth respondent said that if his appearance had been more recognizably Islamic, he also may have experienced discrimination, which he had heard other more visible Muslim teachers complaining about:

Maybe if I was sitting here looking a different way, then I would be saying something different about discrimination. I think it is because of the way I look and the way I sound I do not experience those things

Being visibly Muslim emerged as a barrier particularly for promotion purposes. The participants attributed this to the current unease created by the media hype regarding the perceived threat of Islamic terrorism. The more visible they were as Muslims, the more seriously they felt that discrimination was affecting their career prospects, although, the interviewers were often very subtle in the way they hid their hesitation. The media were often blamed for the way they were received at interviews, and in one case the respondent felt this impacted on the interview outcomes:

People don't say what they feel about you, but I often get the feeling they are very reserved with me. I think it is the media link as it's the main educator of the masses. They (due to what is represented in the media) have a picture of who I am and thus are scared to employ me maybe, they are very good at hiding it however, but not enough - you can always tell. I think since 9/11 it has been very different.

Another participant stated that he knew before he had even answered any questions at an interview he had once attended for the post of the head of department, that he was not going to be offered the job because of his visible Islamic appearance:

When I walked in, I could see the hatred in their faces towards me. They were both white women and I could tell they were both disgusted with the way I looked.

Interestingly, he did eventually get a head of department position in a neighbouring borough and explained that his new head teacher had commented at the interview that he had worked with other Muslim teachers at his previous school. This raises another important issue; that of preparing senior leaders and appointing panels to manage diversity positively. Secondly, this quotation illustrates the perceived difficulty of becoming a senior manager in certain predominately Muslim populated boroughs:

I have found that although there may be many Muslim middle managers in certain areas (he mentioned the name of a borough) for example, they have no Muslim senior managers but lots of Muslim teachers and children. The same goes for (he mentioned three other connecting boroughs). It does seem rather strange. (Rehan)

Although MMT teachers might prefer working in areas with a Muslim majority which might mean that they were less likely to be considered 'outsiders' there seemed to be 
stronger resistance to their appointment to leadership positions in these areas. One participant explained how he had applied for several deputy positions in various heavily Muslim and BME populated boroughs but had not even been short listed, despite having the NPQH. Due to Islam being more visible in these areas, the structural resistance to visible Muslim male teachers emerged as greater.

Another issue highlighted by the participants was that, like other BME teachers, they were generally seen as tools to handle BME students only, and not recognised as mainstream staff capable of senior leadership. They emphasised that they were rather expected to take unofficial lead roles in tackling problems relating to 'Muslim' issues and meeting Muslim parents or to take the lead in dealing with issues pertaining to Muslim children. These teachers definitely saw themselves as role models for Muslim students and were anxious to support them in a 'hostile' environment' but they also wanted to be recognised as mainstream staff capable of being mainstream leaders. They critiqued the stereotypical mentalities of many school leaders, who failed to see them with the potential of 'being a school leader in the true sense' (Osler, 1997).

As with other research on BME teachers (McKenley, Mayhead and Gordon, 2002; Bush, Glover and Sood, 2006), the majority of MMT in this study emphasised that they found it harder to find suitable employment, according to their experience and qualifications. Technologies used to discourage or discriminate against these teachers were often covert, and as such were difficult to identify conclusively. There was also a perception amongst some of the MMT teachers in this study, that there existed a glass ceiling, with regards to career progression that was difficult to break and that, counter-intuitively, this might be particularly strong in areas with a high Muslim population.

\section{Working through Diversity?}

The role of the head teacher and senior management teams as the main agents in establishing harmonious relationships and equality of opportunity throughout the school community appears to be critical. A lack of cultural and/or religious understanding on the part of the head teacher/leaders was often cited by respondents as a cause for teachers' unhappiness in a school. The participating teachers commented that an effective head teacher was the one who understood the needs of all members of his/her staff and responded to them in a fair and unbiased way:

My first head teacher, in a Catholic school with strong discipline was straight talking and fair. He would cover my class for Friday prayers. He had leadership qualities. (He) Would not tolerate (discriminatory) attitudes. He became an executive head that was seconded to other schools - but he was modest. (Rehan)

Conversely, many of the teachers commented that they had bad experiences with head teachers due to the head teacher's approach and lack of sensitivity or understanding towards issues of religion and race. One teacher had been asked by his line manager to design a new multi-racial curriculum for his specialist subject. He consequently prepared a new curriculum which was approved by his line manager and it was posted on the school website to be used as resource by all teachers in the school. However, some time later he was questioned by his head teacher as she felt that some of the 
content, drawn from Islamic texts, was discriminatory towards women. The head teacher asked for part to be removed. The teacher had used the Islamic material as one of a number of examples from different cultures that were relevant to the topic being studied not as examples that he necessarily believed in himself. Despite this, the head teacher continued to have doubts regarding Muhammad's ability to be a senior manager due to what she perceived to be his lack of awareness of equal opportunities. Later, he was given a bad reference by his head teacher, stating that he had a poor understanding of equal opportunities, which had serious implications for his career progression. The participating teacher attributed this attitude to lack of understanding on the part of the head teacher to recognise and work with diversity. Something that could have been avoided by open unbiased discussion:

Some people can only work with certain other people. In that sense it can be discriminatory. For example, Pakistani with Pakistani and English with English. They only have their own set way of working with other people. Their comfort zone is with a certain type of person and therefore will have the effect of being discriminatory.

The role of a head teacher in supporting the achievement/s of individual staff members has been widely documented (London Leadership Centre, 2002; McKenley, Mayhead and Gordon, 2002). Several participating teachers commented that they felt that their career paths in their current schools had been affected by discriminatory attitudes of their head teachers towards employing Muslim or BME staff in senior management teams:

Head teachers set the trend (in the school). Some would (employ a Muslim or a BME teacher on the SMT) - even though they are not particularly comfortable. Some will try - others won't. It all comes down to their honesty to you. Again I am thinking about my own head. Sometimes you have to question their integrity because of what they do, not just one thing but their general attitude. They must have a problem, an issue.

The role of head teachers as the main agents in establishing harmonious working relationships with staff and ensuring equality of opportunity throughout the school community is also seen to be crucial (London Leadership Centre, 2002; McKenley, Mayhead and Gordon, 2002), especially in issues relating to diversity (Lumby and Coleman, 2007). Some participating teachers complained that their head teachers had very little understanding of issues relating to Muslim culture and faith, and as a consequence, albeit unwittingly, created 'in-groups' and 'out-groups' (DiTomaso and Hooijberj, 1996; Lumby and Coleman, 2007) in their schools. Muslim teachers saw themselves as forced to be 'out-groups'. One teacher recalled how he had observed a head teacher insulting a Muslim girl who had been talking in assembly. The head teacher had asked the girl if she had not been listening because of her headscarf:

'Was it that thing around your head that was stopping you listening?' This shows you their mindset. Having said that, there are good head teachers around. I think it eventually boils down to leadership in the end.

As in previous research (Haque, 2004), the majority of the teachers in this study felt that more needed to be done by the government and various agencies, including the 
NCSL, to help Muslim teachers access senior leadership positions in mainstream state schools. Many teachers pointed out the need to change the perceptions and understandings of the incumbent and future head teachers' on issues of diversity, and as such the NCSL should make considerable efforts to incorporate issues of diversity and religious understanding in their courses, as well as to develop leadership courses for Muslims specifically.

There is a need for encouragement from the NCSL and other establishments involved in preparing leaders - that they recognise having Muslim leaders in institutions with large Muslim populations is significantly a good thing. They should promote that. (Sharif)

Head teachers did not always appreciate the impact of associating alcohol with social occasions, which hindered the respondents from participating in various social-cumprofessional activities (Pole, 1999). They not only missed out on opportunities but due to this many colleagues would assume they were unsociable, adding to the negative perception of 'them and us'. All participants commented on this area:

I do not attend the end of year meals or other whole staff celebrations. Myself and other Muslim staff haven't attended due to alcohol. (Muhammad)

A lot of the time socials are organized in pubs. I am reluctant to go there. (Rehan)

School functions are fine. I do not have a problem with places of alcohol, although a lot of brothers do. But I have not been able to go to functions in a pub, as it's the environment. The pub has been specifically designed for the consumption of alcohol. So I don't go to informal functions. (Faris)

Some of the teachers felt that their hesitation or unwillingness to attend such gatherings served indirectly to intensify Muslim/non-Muslim division amongst staff and impacted on their promotions/progression. They felt that more should be done to make it easier for Muslim staff to participate in such activities:

If their intention is to socialize to improve the school atmosphere and teacher performance, then they should accommodate (us). But if it is just social, I guess they can do whatever they want. (Muhammad)

Due to barriers to after-school socialising with other staff and especially with the senior leadership team, the Muslim teachers felt they had to work harder than other staff in similar positions, and their chances of being promoted internally at the school was seriously affected:

I was working harder because I couldn't socialize with them. (Rehan)

I feel that I do have to prove myself in order to stand out positively, because I will not have the chance to socialize with senior staff because of alcohol etc. That will be my only chance, whereas other staff can do so (socialise) and build more positive relationships. (Sharif) 
Bilal felt that his abstention from the pub was a major factor for his not being successful in attempts to be promoted internally:

I normally don't fully attend Christmas party and end of year farewells because of the Alcohol. I listen to the speeches but when the drinks are served I leave. The previous Head teacher would meet staff in the pub, but I didn't attend. If you are not behaving as they do, you are seen as a different person and are treated accordingly.

This feeling of being social 'outsiders' (Lumby and Coleman, 2007; Osler, 2006) emerged as a serious barrier. Participating teachers felt, as other teachers in BME studies (Lumby and Coleman, 2007; Osler, 2006; Rusch, 2004; Sajid, 2005), that being perceived as different from the norm has had a negative impact on their promotion opportunities in their respective schools. However, it would seem that Muslim teachers have additional reasons for feeling they are 'outsiders', which are linked directly to their religious beliefs, and a lack of understanding of them on the part of head teachers and other staff.

\section{Where Do We Go From Here?}

The context created by interacting discourses is complex, sensitive, and volatile, with indications of risk to future destination of young Muslims in particular, and to wider societal cohesion in general. A high level of sociological understanding and analysis is needed to foresee the potential dangers in the intentional or un-intentional discrimination and marginalisation the Muslims are being subjected to. This would have more serious repercussions in the case of male Muslim teachers who could be strong positive role models for young Muslims. This is high time to seriously engage with the barriers to progression of Muslim male teacher to leadership positions with explicit policies and well-defined strategies, instead of leaving it too late for responsive strategies which might not prove effective as in many other cases.

The increasing marginalisation of male Muslim teachers is an intensifying phenomenon as confirmed by the research participants. As in other studies (Osler, 1997; Campbell-Stephens, 2006), some of teachers in this study were significantly overqualified for the jobs they were doing, but had been unsuccessful in gaining promotion. There was also a general feeling that they were not progressing as quickly in their careers as their white counterparts, although no particular reasons could be attributed for this. The participants suggested actions for addressing the situation with particular emphasis on professional development programmes for Muslim teachers, provision of mentoring/coaching, monitoring for equally opportunities in selection/promotion of Muslim teachers, explicit policies, strategies for handling Islamophobia, training programmes for head teachers/senior leaders for managing diversity including faith, countering negative media campaigns, and developing supportive networks, among others.

The participants highlighted the need for focused programmes and courses to cater specifically for the needs of Muslim teachers, to better equip them to become senior managers, and to tackle the challenge of prevailing biases in schools. The NCSL has at present 37 different programmes and courses running under their umbrella, which are aimed at the promotion of leadership in education and only one of these (Equal 
Access to Promotion) is focused on BME intending 'to address the professional development needs of black and minority ethnic (BME) teachers in middle leadership and provide support for them to move on to senior leadership roles' (NCSL Online http://www.ncsl.org.uk/programmes-index/eap-index.htm). However, there is not a single programme focusing on the needs of Muslims or even with a secondary focus on Muslim teachers. The argument often put forward is that such programmes cannot attend to each ethnic group's needs in view of the presence of a large number of ethnic groups in the UK schools. This argument in fact is highly naïve as it refuses to acknowledge the complexity of the MMT issue. It also ignores the emerging scenario and the international political targeting of Muslims which might widen the divide between Muslim/non-Muslim, signalling risk for future societies. Providing support and opportunities for professional development to marginalised groups would not only ensure equal opportunities but would also contribute to societal cohesion. Mackay and Etienne (2006b) argue for specific programmes that target individuals in order to 'review the structural imbalances within organizations that handicap black leaders' experiences of work' (p. 26). This observation becomes more significant in the case of Muslim teachers in the back drop of political developments and media furore about Muslims and its implications for Muslim professionals in the UK and elsewhere.

Despite the recognized benefits of networking (Coleman, 1999; Bush et al., 2005; Campbell-Stephens, 2006) only a small number of the teachers in this study were involved in any network. Not only that they distanced themselves from many mainstream social and networking activities for multiple reasons but many even intentionally avoided being part of even Muslim groups or networks due to a fear of being connected to Islamic extremism. In fact the participating teachers felt so threatened by media vilification of Muslims that they were afraid to engage in networking as indicated earlier in relation to participation in the research project.

Only two out of the ten teachers in this research used networks to aid their career progression and professional development. Upon probing during interviews, it emerged that although many of the teachers interviewed understood and appreciated the benefits of networking they did not participate, either due to a lack of knowledge of existing networks in their community or area or they did not make any conscious efforts to find or get involved in networks because they knew very few teachers who were 'like minded', or who they felt comfortable to share experiences with. Furthermore, they admitted that being Asian and Muslim, they often did not feel that they could confide in white (non-Muslim) colleagues at work because they would not understand their problems or points of view, or that they would be accused of being too sensitive or negative about certain issues:

They (white non-Muslim teachers) don't really see things in the same way. I don't feel comfortable addressing things with them. I've tried on several occasions to explain things but they don't understand and feel we have chips on our shoulders or we are too sensitive or worse still - too extreme. (Karim)

Many studies confirm that a good or inspirational role model aids career progression (Osler, 1997; London Leadership Centre, 2002; Bush et al., 2005; Hayes, 2005; Bush, Glover and Sood, 2006), and mentors can be influential as role models. The participants certainly felt that mentoring contributed to their career progression. 
Reports for NCSL (McKenley, Mayhead and Gordon, 2002; Bush et al., 2005) recommend mentoring for BME teachers aspiring to leadership, but it would seem that this advice was not generally being adhered to by head teachers and schools of the teachers in this study in line with Turner's (2006) claims that government policy and initiatives regarding race and equal opportunities, despite being seemingly accepted by schools, are often not enacted at the ground level.

The need to educate teachers and leaders in schools on issues of diversity was another 'to do' action greatly emphasised by the participants in order to help create harmonious relationships between all staff in these schools - school leaders to help foster a climate of trust and safety amongst all members of the school community. Lumby and Coleman argue that:

The training of black and minority ethnic leaders may help to ensure that the imbalance in the ranks of educational leaders is improved, but all leaders, particularly those from the dominant white, male middle class ranks need to be aware of and understand issues of diversity and ethnicity. (2007, p. 66)

The participants affirmed this by providing examples of the failure on the part of the head teachers and other senior leaders to fully understand and manage diversity in practice, in spite of their being desirous of doing so in some cases. The reasons included a lack of awareness on the part of the head teacher of the culture of the school (Lewis, 1996) and the complexity of the issues of diversity (London Leadership Centre, 2002). In the case of Muslims, the complexity of the issues of diversity is further enhanced because of the inner diversity of this faith group (Shah, 2008). There is no doubt that variations in the level of adherence to different Islamic teachings and 'values' among Muslims add to the challenge of managing these issues. There is also the challenge of the range of diversity of MMT, from different country and cultural heritages, with conflicting interpretations of Islam. This can understandably be frustrating for policy making and implementation. However, the important issues such as career progression of MMTs can't be ignored as too complicated or un-resolvable - these need to be attended to for informed practice. The head teachers and senior leaders need to be trained in tackling these complex and sensitive issues, already made worse by media exploitation of Muslims (Muir and Smith, 2004; Sheridan, 2004; Van Driel, 2004; Sajid, 2005). This is important for preparing a truly representative and effective leadership in education.

The participating MMTs recognised the efforts being made by the government and the NCSL to promote diversity of teaching staff but believed that more needed to be done to rectify the current imbalance. Some went further and argued that the NCSL also needed to be educated on issues pertaining to Muslim teachers, and to incorporate that knowledge to leadership and teacher training courses. Their responses clearly signpost the need for enhanced knowledge and understanding to introduce positive changes in attitudes leading towards improved practice and better policies.

\section{References}

Abbas, T. 2004. After 9/11: British South Asian Muslims, Islamophobia, multiculturalism, and the state. American Journal of Islamic Social Sciences 21, no. 3: 26_38. 
Ahmed, S.T. 2003. Young British Muslims: Social space and active identity. PhD diss. University of Leicester.

Allen, C. 2004. Justifying Islamophobia: A post 9/11 consideration of the European Union and British contexts. American Journal of Islamic Social Sciences 21, no. 3: $1 \_25$.

AMS. 2004. Muslims on education; A position paper. Richmond: The Association of Muslim Social Scientists, Forum Against Islamophobia and Racism and FED 2000.

Basit, T.N., O. McNamara, L. Roberts, B. Carrington, M. Maguire, and D. Woodrow. 2007. 'The bar is slightly higher': The perception of racism in teacher education. Cambridge Journal of Education 37, no. 2: 279_98.

Basit, T.N., L. Roberts, O. McNamara, B. Carrington, M. Maguire, and D. Woodrow. 2006. Did they jump or were they pushed? Reasons why minority ethnic trainees withdraw from initial teacher training courses. British Educational Research Journal 32, no. 3: 387_410.

Brah, A. 1996. Cartographies of diaspora: Contesting identities. London: Routledge.

Bush, T., D. Glover, and K. Sood. 2006. Black and minority ethnic leaders in England: a portrait. School Leadership and Management 26, no. 3: 289_305.

Campbell-Stephens, R. 2006. Moral purpose and the black or global majority school leader. The London Centre for Leadership in Learning, Institute of Education.

Conway, G. 1997. Islamophobia: A challenge for us all. London: The Runnymede Trust.

DfES. 2003. Aiming high: Raising the achievement of minority ethnic pupils. London: DfES.

DiTomaso, N., and R. Hooijberj. 1996. Diversity and the demands of leadership. The

Leadership Quarterly 7, no. 2: 163_87.

Esposito, J.L. 2002. Unholy war: Terror in the name of Islam. Oxford: Oxford University Press.

Foti, R.J., and J.B. Miner. 2003. Individual differences and organizational forms in the leadership process. The Leadership Quarterly 14: 83_112.

Gilborn, D. 2001. Racism, policy and the mis-education of Black children. In Educating our black children: New directions and radical approaches, ed. Richard Myers, 13_27. London: Routledge Falmer.

Gordon, J. 2000. The colour of teaching. Buckingham: Open University Press.

Gronn, P. 1999. The making of educational leaders. London: Cassell.

Hagopian, E.C. 2004. Civil rights in peril: The targeting of Arabs and Muslims. Chicago: Haymarket Books.

Haque, A. 2004. Islamophobia in North America: Confirming the menace. In Confronting Islamophobia in educational practice, ed. B. van Driel, 1_18. Stokeon-Trent: Trentham Books.

Haque, Z., and J.F. Bell. 2001. Evaluating the performance of minority ethnic pupils in secondary schools. Oxford Review of Education 27, no. 3: 358_68.

Home Office. 2001. Religious discrimination in England and Wales. London: Home Office Research, Development and Statistics Directorate.

Jacobson, J. 1998. Islam in transition: Religion and identity among British Pakistani youth. London: Routledge.

Lewis, A. 1996. The implementation of the Code of Practice in primary and secondary schools: A national survey of perceptions of special educational needs coordinators. Warwick: Institute of Education, University of Warwick. 
London Leadership Centre. 2002. Esmee Fairbairn project: An investigation into black and minority ethnic school leaders' access to career progression through the National Professional Qualification for Headship. London: Institute of Education, University of London.

Lumby, J., and M. Coleman. 2007. Leadership and diversity: Challenging theory and practice in education. London: Sage.

Mackay, F., and J. Etienne. 2006. Black managers in further education: Career hopes and hesitations. Educational Management Administration and Leadership 34, no. 1:9_28.

Mayor of London Report. 2004. The educational experiences and achievements of Black boys in London schools 2000_2003. London Development Agency.

McKenley, J., A. Mayhead, and G. Gordon. 2002. Challenge plus: The experience of Black and minority school leaders. National College for School Leadership. http://www.nationalcollege. org.uk/docinfo?id=17115

Milliken, F.J., and L.L. Martins. 1996. Searching for common threads: Understanding the multiple effects of diversity in organizational groups. Academy of Management Review 21, no. 2: 1_32.

Modood, T. 1997. 'Difference', cultural racism and anti-racism. In Debating cultural hybridity multi-cultural identities and the politics of anti-racism, ed. P. Werbner and T. Modood, 154_72. London: ZED Books.

Modood, T. 2006. Multicultural politics: Racism, ethnicity and Muslims in Britain. Edinburgh: Edinburgh University Press.

Modood, T., R. Berthoud, J. Lakey, J. Nazroo, P. Smith, S. Virdee, and S. Beishon. 1997. Ethnic minorities in Britain: Diversity and disadvantage. London: Policy Studies Institute.

MPA. 2004. A report by the Metropolitan Police Authority. BBC News World Edition. http:// news.bbc.co.uk/2/hi/uk_news/england/london/3732169.stm Bhttps://portal.ioe.ac.uk/https/

M2.ioead/exchweb/bin/redir.asp?URL_http://news.bbc.co.uk/2/hi/uk_news/engla nd/london/ 3732169.stm.

Muir, H., and L. Smith. 2004. Islamophobia issues, challenges and action. A report by the Commission on British Muslims and Islamophobia. Stoke-on-Trent: Trentham Books.

National Statistics. 2001. Online Office for National Statistics, www.statistics.gov.uk.

NCSL. 2008. Corporate Plan, 2008/09, http://www.ncsl.org.uk/corporate-plan-0809.pdf.

NCSL. Equal Access to Promotion Index. http://www.ncsl.org.uk/programmesindex/eapindex. htm.

Nielsen, J.S. 1987. Muslims in Britain. Searching for an identity. New Community 8, no. 3: 384_95.

Ofsted. 2002. Recruitment and retention of teachers and headteachers: Strategies adopted by LEAs. Report from the Office of Her Majesty's Chief Inspector of Schools. http:// www.ofsted.gov.uk/Ofsted-home/Publications-and-research

Osler, A. 1997. The education and careers of Black teachers: Changing identities, changing lives. Buckingham: Open University Press.

Osler, A. 2003. Muslim women teachers: Life histories, identities and citizenship. In Muslim women in the United Kingdom and beyond: Experiences and Images women and gender: The Middle East and the Islamic world vol. 2, ed. T. Benn and H. Jawad, 155_71. Netherlands: Brill. 
Osler, A. 2006. Changing leadership in contexts of diversity: Visibility, invisibility and demographic ideals. Policy Futures in Education 4, no. 2: 129_44.

Pole, C. 1999. Black teachers giving voice: Choosing and experiencing teaching. International Journal of Teacher Development 3, no. 3: 313_28.

Powney, P., V. Wilson, S. Hall, J. Davidson, S. Kirk, S. Edward, and S. Mirza. 2003. Teachers' careers: The impact of age, disability, ethnicity, gender and sexual orientation. London: DfES.

Race Relations Act. 2000. Race Relations Amendment Act 2000, Chapter 34 Further extension of 1976 Act to Police and other public authorities. London: HMSO.

Race Relations Act. 2002. The Race Relations Amendment Act. Race Equality Schemes.

Commission on British Muslims and Islamophobia.

Race Relations Act. 2003. The Race Relations Act 1976. Amendment. Regulations 2003. London: HMSO.

Richardson, R. 2004a. The achievement of British Pakistani learners: Work in progress: The report of the RAISE project, 2002_04, funded by Yorkshire Forward. Stoke-on-Trent: Trentham.

Richardson, R. 2004b. Curriculum, ethos and leadership: Confronting Islamophobia in UK education. In Confronting Islamophobia in Educational Practice, ed. B. van Driel, 19_34. Stoke-on-Trent: Trentham Books.

Rusch, E.A. 2004. Gender and race in leadership preparation: A constrained discourse. Educational Administration Quarterly 40, no. 1: 14_46.

Saeed, A. 2007. Media, racism and Islamophobia: The representation of Islam and Muslims in the media. Sociology Compass 1, no. 2: 443_62.

Sajid, A. 2005. Islamophobia: A new word for an old fear. Paper presented at the OSCE Conference on Anti-Semitism and on Other Forms of Intolerance, June 8_9, in Cordoba, Spain.

Shah, S. 2006. Leading multiethnic schools: A new understanding of Muslim youth identity. Educational Management Administration and Leadership 34, no. 2: 21537.

Shah, S. 2008. Leading multi-ethnic schools: Adjustments in concepts and practices for engaging with diversity. British Journal of Sociology of Education 29, no. 5: 523_36.

Sheridan, L. 2004. Islamophobia before and after September 11th 2001. In Confronting Islamophobia in educational practice, ed. B. van Driel, 163_76. Stoke-on-Trent: Trentham Books.

Siraj-Blatchford, I. 1993. Racial equality and effective teacher education. In Race, gender and the education of teachers, ed. I. Siraj-Blatchford, 24_36. Buckingham: Open University Press.

Tomlinson, S. 1990. Multicultural education in white schools. London: Batsford Press.

Turner, L. 2006. Face values: Visible/invisible governors on the board and organisational responses to the race equality agenda. Policy Futures in Education 4, no. 2: $161 \_71$.

van Driel, B. 2004. Introduction. In Confronting Islamophobia in educational practice, ed. B. van Driel, vii_xiii. Stoke-on-Trent: Trentham Books.

\footnotetext{
${ }^{\mathrm{i}}$ The names given to respondents are code names.
} 